\title{
cDNA-SRAP and Its Application in Differential Gene Expression Analysis: A Case Study in Erianthus arundinaceum
}

\author{
Youxiong Que, Liping Xu, Jianwei Lin, Jun Luo, Jingsheng Xu, Jin Zheng, and Rukai Chen \\ Key Lab of Sugarcane Biology and Genetic Breeding, Ministry of Agriculture, Fujian Agriculture and Forestry University, \\ Fuzhou 350002, Fujian, China \\ Correspondence should be addressed to Youxiong Que, queyouxiong@hotmail.com and Liping Xu, xlpmail@yahoo.com.cn
}

Received 29 December 2011; Revised 29 April 2012; Accepted 3 May 2012

Academic Editor: P. B. Kirti

Copyright ( 2012 Youxiong Que et al. This is an open access article distributed under the Creative Commons Attribution License, which permits unrestricted use, distribution, and reproduction in any medium, provided the original work is properly cited.

\begin{abstract}
Erianthus arundinaceum is a wild relative species of sugarcane. The aim of this research was to demonstrate the feasibility of cDNA-SRAP for differential gene expression and to explore the molecular mechanism of drought resistance in E. arundinaceum. cDNA-SRAP technique, for the first time, was applied in the analysis of differential gene expression in E. arundinaceum under drought stress. In total, eight differentially expressed genes with length of 185-427 bp were successfully isolated (GenBank Accession numbers: EU071770, EU071772, EU071774, EU071776, EU071777, EU071779, EU071780, and EU071781). Based on their homologies with genes in GenBank, these genes were assumed to encode ribonuclease III, vacuolar protein, ethylene insensitive protein, aerobactin biosynthesis protein, photosystem II protein, glucose transporter, leucine-rich repeat protein, and ammonia monooxygenase. Real-time PCR analysis on the expression profiling of gene (EU071774) encoding ethylene-insensitive protein and gene (EU071781) encoding ammonia monooxygenase revealed that the expression of these two genes was upregulated both by PEG and ABA treatments, suggesting that they may involve in the drought resistance of E. arundinaceum. This study constitutes the first report of genes activated in E. arundinaceum by drought stress and opens up the application of cDNA-SRAP in differential gene expression analysis in E. arundinaceum under certain stress conditions.
\end{abstract}

\section{Introduction}

As the primary sugar crop, sugarcane is source of $92 \%$ sugar production in China [1]. The cultivated areas of sugarcane are mainly distributed in the dry parts of the southern provinces of China, including Guangdong, Guangxi, Yunnan, Hainan, and Fujian. Cultivation in these dry areas accounts for $85 \%$ of the sugarcane's total acreage in China and drought has become one of the key factors affecting sugarcane production [1]. Breeding sugarcane varieties with higher drought resistance/tolerance is one of the most effective approaches to improve sugarcane production in these areas.

Erianthus arundinaceum, of the Ripidium group, is a wild relative species of sugarcane. It is a large grass with tall stalks, thick and long internodes, narrow leaves, and low sugar contents. With excellent vigor and high fiber content, it can also resist drought, waterlogging, barrenness, and diseases [2]. Additionally, it has a good perennial ratooning ability (the ability to regrow after harvesting) and can produce more tillers at a fast growth rate and with wide adaptability. Zhang et al. (2004a) investigated change of enzyme activity involved in the reactive oxygen species metabolism and osmoregulation both in sugarcane and E. arundinaceum under water stress. The results indicated that $E$. arundinaceum showed higher drought tolerance ability than sugarcane at the physiological level [3]. The experiment on drought- and salt-tolerance of $E$. arundinaceum conducted by Guo et al. (2005) and Zhang et al. (2004b) also revealed that E. arundinaceum possessed better tolerance than sugarcane in both physical appearance and metabolism [3, 4]. Therefore, characterizing and utilizing E. arundinaceum germplasm, especially identification and isolation of its drought-tolerance gene for engineering drought-resistance sugarcane cultivars, might be a good approach in the exploitation of E. arundinaceum resources. Previous studies on E. arundinaceum were focused mainly on its morphology [5], chromosome aberrations [6], and 
physiological resistance [3, 4]. A study of E. arundinaceum's drought-tolerance mechanism at the molecular level is needed.

Sequence-related amplified polymorphism (SRAP) is a PCR-based molecular marker technique developed by Li and Quiros [7]. This technique has the advantages of being simple, effective, and fast. Analysis and detection of the fragment length polymorphism with SRAP primers can be carried out with either genomic DNA (SRAP) or CDNA (cDNA-SRAP) as template. So far, SRAP has been successfully applied to research of several crops including cotton, melon, buffalograss, peach, and squash with application in various areas including genetic map construction $[7,8]$, molecular diversity analysis $[9,10]$, and comparative genomic study [11]. The cDNA-SRAP technique has been proved to be suitable for analysis of differential gene expression in several kinds of plants. Li et al. (2003) conducted SRAP amplification using cDNA template from intraspecific hybrids between cauliflower and cabbage, and 281 polymorphic bands were obtained with 48 primer combinations from $88 \mathrm{cDNA}$ samples [11]. Lu and $\mathrm{Wu}$ (2006) carried out a differential display study on salt-tolerance of Spartina angelica using cDNA-SRAP in which a differentially expressed fragment with $30 \%$ similarity to the $\beta-1,3$-glucanase of rice was identified [12]. Deng et al. (2007) applied cDNA-SRAP in the study of differential gene expression in the restore and maintainer lines of cabbage. Amplification with 30 SRAP primer combinations was performed and two differentially expressed genes were obtained [13]. Ma et al. (2008) analyzed differential genes related to seed-coat color in Brassica napus L. by cDNA-SRAP technique and a total of 2100 bands were amplified with 996 SRAP primer combinations. In total, 12 seed-coat-related fragments were identified [14].

In the present study, cDNA-SRAP technique, for the first time, was used to screen differentially expressed genes related to drought-tolerance in E. arundinaceum. Subcloning, sequencing, and bioinformatics analysis of these differentially expressed genes were then conducted. After that, the differential expression of all these genes was validated with Real-time PCR analysis. Real-time PCR analysis was also carried out to study the expression profiling of gene encoding ethylene-insensitive protein and gene encoding ammonia monooxygenase in E. arundinaceum under ABA (abscissic acid) and PEG (polyethylene glycol) treatments. This study presents the first report of the feasibility of cDNASRAP for revealing the molecular mechanism of droughttolerance and also opens up its application in differential gene expression in E. arundinaceum.

\section{Materials and Methods}

2.1. Plant Materials and Treatments. E. arundinaceum plants were collected from the campus of Fujian Agriculture and Forestry University. They were planted in two groups of three pots $(50 \mathrm{~cm}$ height $\times 35 \mathrm{~cm})$ and three plants per pot. Both groups were watered normally (once per day) until the plants reached one meter high. After that, one group was watered as usual (Control, CK) while watering was discontinued to the other (Treatment, Tr). Seven days later, mildly stressed leaves sample of the Tr plant and the CK plant were collected for the first time. After the water supply has been cut off for about 15 days, the leaves of $E$. arundinaceum exhibited moderately stressed growth were sampled for the second time $[15,16]$. During sampling, all three plants in each pot were sampled, twelve youngest fully expanded leaves from $\mathrm{Tr}$ and CK pot, respectively. A mixture of an equal amount from the above two samples was used in total RNA extraction for cDNASRAP analysis.

For the sample preparation in Real-time PCR analysis, plants of $E$. arundinaceum were cultivated in sands in ten pots $(50 \mathrm{~cm}$ height $\times 35 \mathrm{~cm})$, three plants in each pot. When the plants reached $80 \mathrm{~cm}$ high, they were divided into two groups, five pots in each group. For group one, the plants in one pot were supplied with water normally, while for the other four pots, the sands were removed and the plants were immersed into water for one-day recovery and after that cultured in the water containing 30\% PEG (polyethylene glycol) 6000 . Leaves were collected at $0 \mathrm{~h}, 3 \mathrm{~h}, 6 \mathrm{~h}, 12 \mathrm{~h}$, and $24 \mathrm{~h}$ time points of PEG stress, respectively $[15,16]$. For group two, ABA (abscisic acid) $(10 \mathrm{mg} / \mathrm{L})$ was directly sprayed and the leaves were collected at $0 \mathrm{~h}, 2 \mathrm{~h}, 4 \mathrm{~h}, 12 \mathrm{~h}$ and $24 \mathrm{~h}$ time points after ABA spraying, respectively $[15,16]$. Samples were fixed with liquid nitrogen immediately and stored at $-85^{\circ} \mathrm{C}$ until RNA extraction.

2.2. RNA Extraction. Trizol (Invitrogen) was used to extract the total RNA following procedures described in Que et al. (2008) [17]. The RNA quality was determined by agarose gel electrophoresis and ultraviolet spectrophotometer analysis.

2.3. cDNA-SRAP Analysis. The reverse transcription reaction contained $2 \mu \mathrm{L} 5 \times$ RT buffer, $0.5 \mu \mathrm{L} 10 \mathrm{mmol} \mathrm{L}^{-1}$ dNTPs, $1 \mu \mathrm{L} 10 \mu \mathrm{mol} \mathrm{L}^{-1}$ random hexamer, $50 \mathrm{U}$ RTase reverse transcriptase, $0.25 \mu \mathrm{L}$ RNase inhibitor, and $1 \mu \mathrm{L}$ total RNA $(500 \mathrm{ng}$ ) as template. The volume was adjusted to $10 \mu \mathrm{L}$ with RNase free water. The reaction was incubated at $42^{\circ} \mathrm{C}$ for $10 \mathrm{~min}, 95^{\circ} \mathrm{C}$ for $2 \mathrm{~min}$ and then kept at $5^{\circ} \mathrm{C}$ for $5 \mathrm{~min}$.

In CDNA-SRAP analysis, the primer sequences were taken from $\mathrm{Li}$ et al. $[7,11]$. The total reaction volume was $50 \mu \mathrm{L}$ containing $5 \mu \mathrm{L} 10 \times$ PCR Buffer $(15 \mathrm{mmol} / \mathrm{L}$ $\mathrm{MgCl}_{2}$ plus), $3.75 \mu \mathrm{L}$ dNTPs ( $10 \mathrm{mmol} / \mathrm{L}$ ), $1.25 \mathrm{U}$ Taq DNA polymerase enzyme, $1.5 \mu \mathrm{L}$ forward and reverse primers $(10 \mu \mathrm{mol} / \mathrm{L})$, respectively, and $100 \mathrm{ng}$ reverse transcription products of cDNA as the template. The reaction procedure was as follows: predenaturation at $94^{\circ} \mathrm{C}$ for $5 \mathrm{~min}, 5$ cycles (denaturation at $94^{\circ} \mathrm{C}$ for $1 \mathrm{~min}$, annealing at $35^{\circ} \mathrm{C}$ for $1 \mathrm{~min}$, and extension at $72^{\circ} \mathrm{C}$ for $1 \mathrm{~min}$ ), then 35 cycles $\left(94^{\circ} \mathrm{C}\right.$ for $1 \mathrm{~min}, 50^{\circ} \mathrm{C}$ for $1 \mathrm{~min}$, and $72^{\circ} \mathrm{C}$ for $1 \mathrm{~min}$ ) and the final extension at $72^{\circ} \mathrm{C}$ for $10 \mathrm{~min}$. The amplified products of the cDNA-SRAP were concentrated to about $10 \mu \mathrm{L}$ with the centrifugal freeze drying system (Marain Chriset, Germany). The whole volume was loaded onto the $1.6 \%$ agarose gel (containing $0.1 \% \mathrm{~EB}$ ) for electrophoresis and imaged with a Bio-Rad Gel Imaging System (Hercules, CA USA). The Agarose SFR was purchased from Sangon Biological Engineering Technology \& Services CO., Ltd. 


\subsection{Bioinformatics Analysis and Real-Time PCR Validation of} Differentially Expressed Genes. After differentially expressed genes were subcloned according to PMD18-T procotol and then sequenced, tBlastx was used to conduct the homology search in GenBank to identify the potential function of these genes $[18,19]$. The $25 S$ rRNA gene of E. arundinaceum was selected as the internal control gene [20] and the Primer premier 5.0 was used for primer design (Table 1). The instrument used in Real-time PCR analysis was ABI PRISM7500 Real-Time PCR System (Carlsbad, CA USA).

The cDNA reverse transcription product, the same as that used in cDNA-SRAP analysis, was used as template in Realtime PCR validation. The $25 \mu \mathrm{L}$ reaction volume contained $12.5 \mu \mathrm{L}$ SYBR Primix ExTaq $(2 \times), 0.5 \mu \mathrm{L}$ forward and reverse primers $(10 \mu \mathrm{mol} / \mathrm{L})$, respectively, $2.5 \mu \mathrm{L}$ cDNA template $(40 \mathrm{ng} / \mu \mathrm{L})$ and $9 \mu \mathrm{L}$ sterile water. Each sample was replicated three times. The reaction conditions were predenatured at $95^{\circ} \mathrm{C}$ for $30 \mathrm{~s}$, and then a total of 40 cycles $\left(95^{\circ} \mathrm{C} 5 \mathrm{~s}\right.$ and $60^{\circ} \mathrm{C} 34 \mathrm{~s}$ ). When the reaction finished, the melting curve was analyzed. The data was analyzed with $2^{-\Delta \Delta \mathrm{Ct}}$ method [21-24], in which $\Delta \Delta \mathrm{Ct}=(\mathrm{Ct} \text {, target gene }-\mathrm{Ct}, 25 \mathrm{~S})_{\text {Timex }}{ }^{-}$ $(\mathrm{Ct} \text {,target gene }-\mathrm{Ct}, 25 \mathrm{~S})_{\text {Time } 0}$. The CT.target gene and CT.25S were CT values of ethylene insensitive gene or ammonia monooxygenase gene in E. arundinaceum and the 25S rRNA gene, respectively, and Time ${ }_{x}$ was the time points of sampling after the treatment of ABA or PEG. Time ${ }_{0}$ was the control at $0 \mathrm{~h}$.

2.5. Expression Profiling of Ethylene Insensitive Gene and Ammonia Monooxygenase Gene in E. arundinaceum by RealTime PCR. The primers of control gene (25S rRNA) of E.arumdinaceum, which proved to be the same as sugarcane 25S rRNA gene, and the primers for ethylene insensitive gene (EU071774) and ammonia monooxygenase gene (EU071781) were shown in Table 1. The Real-time PCR reaction and procedure, which was the same as that in 2.4, were use to study the expression profiling of ethylene insensitive gene and ammonia monooxygenase gene in $E$. arundinaceum under PEG and ABA treatments.

\section{Results}

3.1. cDNA-SRAP Analysis of Differential Gene Expression in E. arundinaceum under Drought Stress. Agarose gel electrophoresis and ultraviolet spectrophotometer analysis revealed that RNA extracted in this study can meet the quality requirement for CDNA-SRAP analysis. Amplification products presented in all cDNA-SRAP reactions indicated that the reaction conditions adopted here were suitable for the analysis of cDNA-SRAP differential display in $E$. arundinaceum. In order to ensure reliability of differential expression, only bands with significant differential expression were further characterized. Based on this standard, only 13 differentially expressed genes of E. arundinaceum under drought stress were selected for further analysis (Figure 1), among which eight showed upregulated expression after treatment and the expression of the remaining five were downregulated. They were sequenced and the tBlastx program was used to find out homology with reported

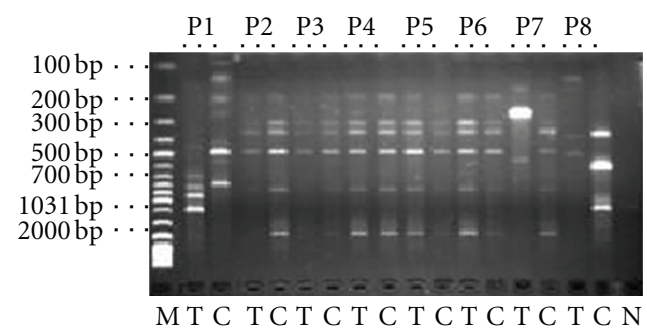

FIGURE 1: The amplified result of eight primer combinations. Notes: M, Marker; T, Treatment; C, Control; B, Blank or negative control; $\mathrm{P} 1-\mathrm{P} 8$, primer combinations.

genes. Sequence alignment indicated that 10 out of these 13 differentially expressed genes showed homologies to certain genes from 32\% to $96 \%$ in GenBank, while the other three showed no significant homology with reported genes (Table 2). It should be noted that, although the sequence alignment of 13 differentially expressed genes of $E$. arundinaceum emerged from cDNA-SRAP analysis seems to not link directly with drought stress from tBlastx, because of their differential expression before and after the drought stress and the drought tolerance mechanism is complex, they should be potential candidate drought-stress-related genes in E. arundinaceum.

3.2. Validation of Differential Expression of Genes by RealTime PCR. Real-time PCR assay was performed to validate differential expression of genes screened in cDNA-SRAP analysis. The primers were designed based on the sequences of 13 differentially expressed genes identified in the cDNASRAP analysis, and the cDNA from E. arundinaceum before and after drought stress was selected as the template (the same as that used in the cDNA-SRAP analysis) in Real-time PCR analysis (Figure 2). The results revealed that three genes, which termed as M5E12T11, M2E15T15, and M2E13C7, failed to be amplified, which may due to false positive, while the other 10 genes showed effective amplification. Except for two fragments, M3E6T19 and M4E5C9, whose expression was opposite to that in cDNA-SRAP analysis (false positive), all the other eight genes were validated to be truly differentially expressed in E. arundinaceum under drought stress (Figure 2). From above, the application of cDNA-SRAP in the study of differential gene expression in E. arundinaceum was feasible.

\subsection{Expression Profiling of Ethylene Insensitive Gene and} Ammonia Monooxygenase Gene by Real-Time PCR. ABA is a plant hormone involved in signal transduction of drought stress response and PEG is a good treatment to mimick drought stress $[25,26]$. In this study, E. arundinaceum leaves, which had not been treated by PEG and ABA stresses, were used as the control (CK), respectively, and the amount of their expression was defined as one unit. Real-time PCR analysis was conducted to quantify the expression level of ethylene insensitive gene and ammonia monooxygenase gene during the four time points of both PEG and ABA stresses, and the results were shown in Figures 3 and 4. Figure 3(a) 
Table 1: Primer sequences used in Real-time PCR analysis.

\begin{tabular}{|c|c|c|}
\hline Primer code & Primer sequence $\left(5^{\prime}-3^{\prime}\right)$ & Primer sequence $\left(5^{\prime}-3^{\prime}\right)$ \\
\hline M2E13C7 & 5'-CTAGCTCTGGGTTCGAGTGG-3' & $5^{\prime}$-ACCAGGATGAAGCTTGGATG-3' \\
\hline M3E3T8 & 5'-GTCCCAACCAAGCAAACAGT-3' & 5'-AATTCTGGTGGGAGTTGTGC-3' \\
\hline M4E5C9 & 5'-GTTTTCGGTGATGGTGTCCT-3' & 5'-GCCCAAAGCATCTCTCACTC-3' \\
\hline M4E12C10 & 5'-TGCCGCTCACGAATATATGA-3' & 5'-GCTTCCCTTGAAACATGGAA-3' \\
\hline M5E12T11 & 5'-GTCTGAGGCTAACCGGATCA-3' & 5'-AGATCAGCAGGGACGAGGTA-3' \\
\hline M1E4T12 & 5'-ATCCACTGCTCCTGAAACCT-3' & 5'-TAGGAACCTTCTCCAAAGGC-3' \\
\hline M2E15T15 & 5'-AGGAGTGCTCTGTTGGCAGT-3' & 5'-TTGGGAGGCAAGAAGTCATC-3' \\
\hline M2E15C16 & 5'-GCTTCACCAATGGAGGCTAA-3' & 5'-TATTGCTGACGTTGCCTTTG-3' \\
\hline M2E15T17 & 5'-CGCCATCTCCATATCTGGTT-3' & 5'-TTAGGCCCAATTTCGCTAAG-3' \\
\hline M3E6T19 & $5^{\prime}$-CCAAAAGCGAAAAGTTGAGC-3' & $5^{\prime}$-CGCAGTTTGACAGCACAGAT-3' \\
\hline M3E6T20 & 5'-AACCCCAAAAGCGAAAAGTT-3' & 5'-CAGCACAGATTTGGCTTTCA-3' \\
\hline M4E2T23 & 5'-AAATATTGGCCGCTTGTTTG-3' & 5'-GCAGTTCTCGTGAGGGACTC-3' \\
\hline M4E2C24 & 5'-GATGCAGCCTTAAGGAGAGG-3' & 5'-TGTCCCAAATGCAATGAGTT-3' \\
\hline $25 \mathrm{~S} r R N A$ & 5' - GCAGCCAAGCGTTCATAGC-3' & $5^{\prime}$-CCTATTGGTGGGTGAACAATCC-3' \\
\hline
\end{tabular}

TABLE 2: Sequence analysis of differential expressed genes screened in cDNA-SRAP analysis.

\begin{tabular}{|c|c|c|c|c|}
\hline Clone ID & Accession No. & SRAP Primer & Homologous protein (Homology) & $\begin{array}{l}\text { Sequences } \\
\text { Length (bp) }\end{array}$ \\
\hline M2E13C7 & EU071769 & $\begin{array}{l}5^{\prime} \text {-TGAGTCCAAACCCGGAGC-3' } \\
5^{\prime} \text {-GACTGCGTACGAATTGGT-3' }\end{array}$ & hypothetical protein $(92 \%)$ & 269 \\
\hline M3E3T8 & EU071770 & $\begin{array}{l}5^{\prime} \text {-TGAGTCCAAACCCGGAAT-3' } \\
5^{\prime} \text {-GACTGCGTACGAATTGAC-3' }\end{array}$ & ribonuclease III (40\%) & 776 \\
\hline M4E5C9 & EU071771 & $\begin{array}{l}5^{\prime} \text {-TGAGTCCAAACCCGGACC-3' } \\
5^{\prime} \text {-GACTGCGTACGAATTAAC-3' }\end{array}$ & transcription-repair factor $(50 \%)$ & 271 \\
\hline M4E12C10 & EU071772 & $\begin{array}{l}\text { 5'-TGAGTCCAAACCCGGACC-3' } \\
5^{\prime} \text {-GACTGCGTACGAATTGTC-3' }\end{array}$ & vacuolar protein $(60 \%)$ & 342 \\
\hline M5E12T11 & EU071773 & $\begin{array}{l}\text { 5'-TGAGTCCAAACCCGGAAG-3' } \\
5^{\prime} \text {-GACTGCGTACGAATTGTC-3' }\end{array}$ & autophagy-related protein $(90 \%)$ & 185 \\
\hline M1E4T12 & EU071774 & $\begin{array}{l}5^{\prime} \text {-TGAGTCCAAACCCGGATA-3' } \\
5^{\prime} \text {-GACTGCGTACGAATTTGA-3' }\end{array}$ & ethylene insensitive protein $(89 \%)$ & 373 \\
\hline M2E15T15 & EU071775 & $\begin{array}{l}5^{\prime} \text {-TGAGTCCAAACCCGGAGC-3' } \\
5^{\prime} \text {-GACTGCGTACGAATTCTG-3' }\end{array}$ & hypothetical protein $(96 \%)$ & 300 \\
\hline M2E15C16 & EU071776 & $\begin{array}{l}5^{\prime} \text {-TGAGTCCAAACCCGGAGC-3' } \\
5^{\prime} \text {-GACTGCGTACGAATTCTG-3' }\end{array}$ & aerobactin biosynthesis protein $(37 \%)$ & 373 \\
\hline M2E15T17 & EU071777 & $\begin{array}{l}5^{\prime} \text {-TGAGTCCAAACCCGGAGC-3' } \\
5^{\prime} \text {-GACTGCGTACGAATTCTG-3' }\end{array}$ & photosystem II protein $(83 \%)$ & 408 \\
\hline M3E6T19 & EU071778 & $\begin{array}{l}5^{\prime} \text {-TGAGTCCAAACCCGGAAT-3' } \\
5^{\prime} \text {-GACTGCGTACGAATTGCA-3' }\end{array}$ & glucose-transport member (32\%) & 362 \\
\hline M3E6T20 & EU071779 & $\begin{array}{l}5^{\prime} \text {-TGAGTCCAAACCCGGAAT-3' } \\
5^{\prime} \text {-GACTGCGTACGAATTGCA-3' }\end{array}$ & hypothetical protein $(32 \%)$ & 361 \\
\hline M4E2T23 & EU071780 & $\begin{array}{l}5^{\prime} \text {-TGAGTCCAAACCCGGACC-3' } \\
5^{\prime} \text {-GACTGCGTACGAATTTGC-3' }\end{array}$ & leucine rich repeat protein $(33 \%)$ & 326 \\
\hline $\mathrm{M} 4 \mathrm{E} 2 \mathrm{C} 24$ & EU071781 & $\begin{array}{l}5^{\prime} \text {-TGAGTCCAAACCCGGACC-3' } \\
5^{\prime} \text {-GACTGCGTACGAATTTGC-3' }\end{array}$ & ammonia monooxygenase (35\%) & 427 \\
\hline
\end{tabular}

shows that under PEG stress, the expression level of ethylene insensitive gene increased gradually, especially at the time point of $12 \mathrm{~h}$, at which the amount was 2.7 times that of the control. The results shown in Figure 3(b) indicate that ABA stress could also upregulate the expression of ethylene insensitive gene in E. arundinaceum, but not as obvious as that of PEG stress. Figure 4(a) shows that, under PEG stress, the expression level of ammonia monooxygenase gene increased gradually, especially at the time point of $24 \mathrm{~h}$, at which the amount was 3.3 times that of the control. However, just as indicated in Figure 4(b), compared to PEG stress, ABA stress could only slightly upregulate the expression of ammonia monooxygenase gene in E. arundinaceum. In other words, the expression of ethylene insensitive gene and 


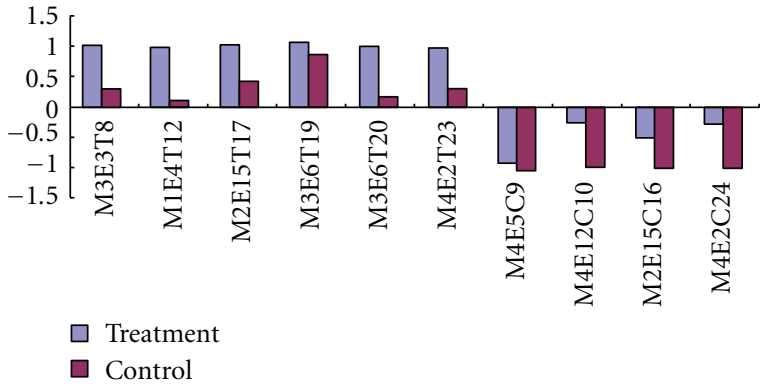

FIGURE 2: Validation of 10 differentially expressed genes screened in cDNA-SRAP by Real-time PCR.

ammonia monooxygenase gene in $E$. arundinaceum could be regulated by both ABA and PEG stresses, ABA- and PEGdependant, which suggested that both of these two genes probably took part in the drought resistance/tolerance of E. arundinaceum and further confirmed the feasibility of cDNA-SRAP in the study of differential gene expression in E. arundinaceum.

\section{Discussion and Conclusion}

This is the first demonstration of differential gene expression in E. arundinaceum under drought stress with cDNA-SRAP and agarose gel electrophoresis techniques. In total, eight differentially expressed genes were identified (GenBank Accession numbers: EU071770, EU071772, EU071774, EU071776, EU071777, EU071779, EU071780, and EU071781). The results of tBlastx analysis in GenBank showed that these genes shared homologies with genes encoding ribonuclease III, vacuolar protein, ethylene insensitive protein, aerobactin biosynthesis protein, photosystem II protein, glucose transporter, leucine-rich repeat protein, and ammonia monooxygenase. Real-time PCR analysis demonstrated that the expression of ethylene insensitive gene and ammonia monooxygenase gene in E. arundinaceum was regulated by PEG and ABA, suggesting they may involve in droughttolerance with its expression characteristics of ABA- and PEG-dependant.

In CDNA-SRAP technique, the core sequence of the forward primer (CCGG) and the reverse primer (AATT) and the changing annealing temperature ensure the stability of the amplification results [11-14]. More primer combinations can be obtained through replacing the three selective bases at the $3^{\prime}$ ends of the forward and reverse primers. At the same time, as the forward and reverse primers can combine with each other freely, a series of primer combinations can be achieved with only a small number of primers. Not only can this reduce the cost of the primer synthesis but also improve the efficiency of primer use. Since the forward and reverse primers are targeted at relatively conserved exons, introns with large variation, respectively, or promoter and intervening sequence, most SRAP markers are evenly distributed in the whole genome with high-frequency codominance. Additionally, while it mainly amplifies the open reading frame (ORF) of the genome, the SRAP technique can increase the correlation between amplicon and phenotype, thus better reflects the phenotypic difference of plant materials at genetic level [7]. In addition, cDNA-SRAP technique, with its simple procedure, involves only reverse transcription, PCR amplification, and gel electrophoresis detection. Compared with cDNA-AFLP and DDRT-PCR $[27,28]$, cDNA-SRAP has better repeatability and more amplified fragments, and it can also detect differential gene expression in multiple samples simultaneously with less cost. Contrary to the ESTs acquirement through cDNA library construction and sequencing, cDNA-SRAP can detect expressed genes more uniformly [11]. Furthermore, as SRAP usually produces high-intensity fragments with few overlaps, the corresponding primers can even be used directly for sequencing of the target fragments [7]. Among the total 13 differentially expressed genes screened in cDNA-SRAP analysis, eight were validated by Real-time PCR analysis to be true differentially expressed and the corresponding accuracy rate was $61.5 \%$. It was noteworthy that when the $50 \mu \mathrm{L}$ PCR reaction was adopted in the preexperiment, more stable results could be obtained compared with that of $25 \mu \mathrm{L}$ PCR reaction. This study also revealed that PCR product could be concentrated by the freeze-drying centrifugal system to increase its concentration, which was helpful to obtain clearer band in agarose gel electrophoresis, while electrophoresis of PCR products without concentration showed rather weak bands. In conclusion, cDNA-SRAP analysis is a useful tool for understanding new putative transcripts and/or genes that are differentially expressed in E. arundinaceum in response to certain kind of stress.

To our knowledge, ethylene insensitive gene is a central component of the ethylene signaling pathway, and it is also a bifunctional transducer of ethylene and stress responses [29]. This gene has been shown to be involved in the regulation of abiotic and biotic stresses, including $\mathrm{ABA}$ treatment, ozone stress, high salt, oxidative stress, and disease resistance [30-32]. Ammonia monooxygenase (AMO) is an ammonia-dependent metalloenzyme which catalyzes the oxidation of ammonia to hydroxylamine [33]. However, it is unclear whether ethylene insensitive gene also plays a role in the regulation of the drought stress response in $E$. arundinaceum and there is no report on the expression and biological function of ammonia monooxygenase gene in plants. Previous studies have shown that ABA is a key plant hormone involved in signal transduction of drought stress response and plant growth regulation [25]. Drought stress can increase ABA synthesis and accumulation, and when the stress reduces, the synthesized ABA degrades quickly [34]. A majority of genes responsive to the biotic and abiotic stresses can be upregulated by $\mathrm{ABA}$, and, especially, the $\mathrm{ABA}$ and osmotic stress are correlated with each other in activating the expression of the stress response genes [35]. The research carried out by Nieves et al. (2001) revealed that the droughttolerance of sugarcane could be improved by the exogenously applied $\mathrm{ABA}$ through increasing the content of polyamine [36]. Beaudoin et al. (2000) demonstrated the existence of extensive interactions between the ABA and ethylene insensitive gene in Arabidopsis abil-1 mutant and found that the ethylene insensitive gene inhibits ABA signaling in seeds 


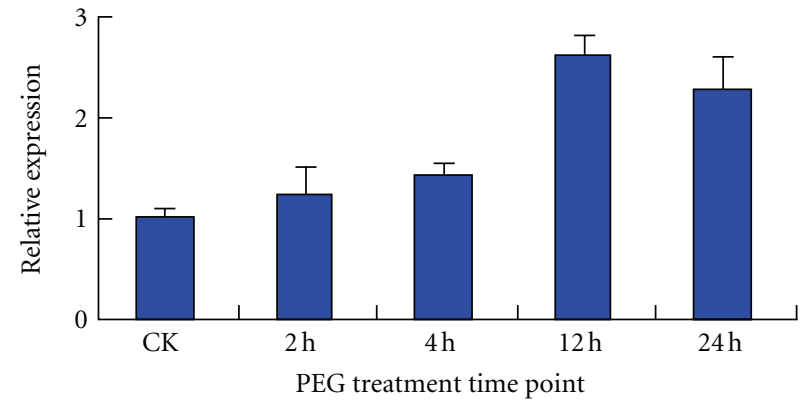

(a)

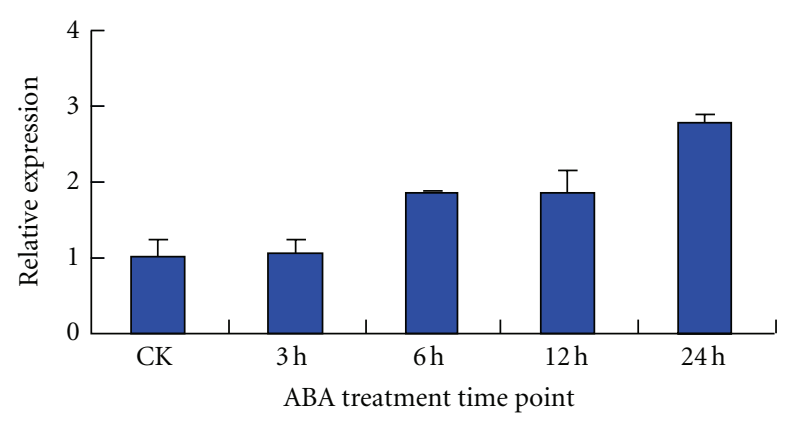

(b)

FIGURE 3: Expression profiling of ethylene insensitive gene (EU071774) in E. arundinaceum under PEG (a) and ABA (b) treatments.

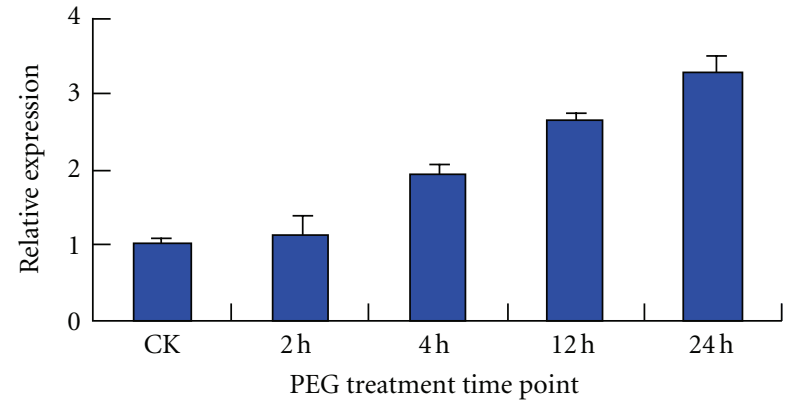

(a)

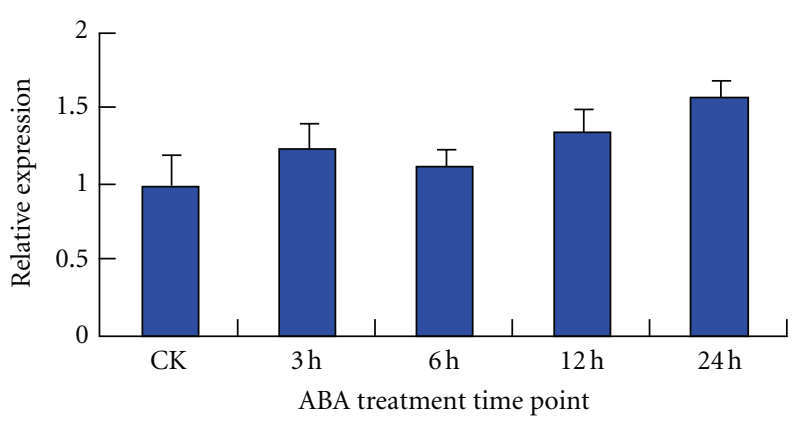

(b)

FIGURE 4: Expression profiling of ammonia monooxygenase gene (EU071781) in E. arundinaceum under PEG (a) and ABA (b) treatments.

[37]. Wang et al. (2007) found that one ethylene insensitive gene, EIN2, plays an important role in mediating cross-links between several hormone response pathways, including ABA, and this gene can regulate plant response to osmotic and salt stress through an ABA-dependent pathway in Arabidopsis [31]. At the same time, some genes, such as rd29A, kin1, cor6.6, were not dependent on ABA but could be induced by drought, high salinity, and coldness [38]. PEG could produce osmotic stress, and the exogenous PEG treatment could, therefore, be used as a simulated condition of drought stress [26]. Zhang et al. (2004) carried out physiological study on the application of PEG in the osmotic stress of plants and found that the PEG with high molecular weight was the ideal material to regulate the water potential for simulation of dry soil. In addition, liquid culture with PEG solution is a common and ideal system in the studies of osmotic stress of plants [39]. It can simulate a series of physiological and biochemical reactions related to drought-tolerance in plants. In this study, the expression of ethylene insensitive gene and ammonia monooxygenase gene in E. arundinaceum was upregulated by PEG and ABA and it was thus inferred that these two genes may play a role in the drought-tolerance of this plant, which needed to be further confirmed.

\section{Acknowledgments}

This research was funded by the earmarked fund for Modern Agro-industry Technology Research System (CARS-20),
National Natural Science Foundation of China (31101196), and National High Technology Research and Development Program of China (863 Program) Project (2007AA100701). The authors appreciate all ideas and constructive criticism from the reviewers, especially Qiudeng Que in Syngenta, Usman Hammed and Khushi Muhammad in University of the Punjab Lahore, Pakistan, and Michael P Grisham in USDA-ARS, Sugarcane Research Unit, Louisiana, USA.

\section{References}

[1] R. K. Chen, Theory and Practice in Modern Sugarcane Breeding, China Agriculture Press, Beijing, China, 2003.

[2] B. Ram, T. V. Sreenivasan, B. K. Sahi, and N. Singh, "Introgression of low temperature tolerance and red rot resistance from Erianthus in sugarcane," Euphytica, vol. 122, no. 1, pp. 145-153, 2001.

[3] M. Q. Zhang, J. Pan, X. Y. Wen, and R. K. Chen, "Analysis of the difference of drought tolerance in Saccharum officinarum and Erianthus arundinaceum Retz," Chinese Journal of Tropical Crops, vol. 25, pp. 50-54, 2004.

[4] Y. Guo, A. L. Yu, and M. Q. Zhang, "Use and characterisation of the genuine intergeneric hybrids from the cross between Saccharum officinarum L. and Erianthus arundinaceum Retz ( $\square$ ) - salinity tolerance in Saccharum officinarum and Erianthus arundinaceum," Chinese Journal of Tropical Crops, vol. 26, pp. 88-93, 2005.

[5] Q. H. Yang, F. H. Xiao, S. C. He, and F. S. Li, "Studies on the chromosomes and botanical characters of Erianthus 
Arundinaceum(Retz) Jeswiet," Journal of Yunnan Agricultural University, vol. 12, no. 4, pp. 253-256, 1997.

[6] W. R. Liu, Z. H. Deng, M. Q. Zhang, X. L. Zhuo, C. Fu, and C. M. Zhang, "Use and characterization of the genuine intergeneric hybrids from the cross of Saccharum spp. and E. arundinaceum Retz-III. Cytogenetic analysis for the hybrid and backcross progeny of S. officinarum L. and Erianthus sect," Acta Agronomica Sinica, vol. 30, no. 11, pp. 1093-1096, 2004.

[7] G. Li and C. F. Quiros, "Sequence-related amplified polymorphism (SRAP), a new marker system based on a simple PCR reaction: its application to mapping and gene tagging in Brassica," Theoretical and Applied Genetics, vol. 103, no. 2-3, pp. 455-461, 2001.

[8] Z. Lin, D. He, X. Zhang et al., "Linkage map construction and mapping QTL for cotton fibre quality using SRAP, SSR and RAPD," Plant Breeding, vol. 124, no. 2, pp. 180-187, 2005.

[9] M. Ferriol, B. Picó, and F. Nuez, "Genetic diversity of a germplasm collection of Cucurbita pepo using SRAP and AFLP markers," Theoretical and Applied Genetics, vol. 107, no. 2, pp. 271-282, 2003.

[10] E. Kosman and K. J. Leonard, "Conceptual analysis of methods applied to assessment of diversity within and distance between populations with asexual or mixed mode of reproduction," New Phytologist, vol. 174, no. 3, pp. 683-696, 2007.

[11] G. Li, M. Gao, B. Yang, and C. F. Quiros, "Gene for gene alignment between the Brassica and Arabidopsis genomes by direct transcriptome mapping," Theoretical and Applied Genetics, vol. 107, no. 1, pp. 168-180, 2003.

[12] Y. Q. Lu and W. R. Wu, "Identification of salt-responsive genes in English cordgrass (Spartina anglica) roots using SRAP technique," Journal of the Zhejiang University, vol. 32, no. 5, pp. 511-514, 2006.

[13] X. H. Deng, S. N. Zhang, and X. L. Hou, "Differential expression analysis of bud of pol CMS and its maintainter line of Brassica rapa.ssp. chinensis through SRAP," Acta Horticulturae Sinica, vol. 34, pp. 655-658, 2007.

[14] A. F. Ma, J. N. Li, L. Chen, W. Qian, F. Y. Fu, and L. Z. Liu, "Differential display of related genes to seed-coat color by cDNA-SRAP in Brassica napus L," Acta Agronomica Sinica, vol. 34, pp. 526-529, 2008.

[15] J. S. Zhang, Expression profile of Erianthus arundinaceus cDNA microarray under drought-stress and key drought-resistant genes cloning [Dissertation for doctoral degree], Fujian Agriculture and Forestry University, 2007.

[16] W. L. Liu, J. S. Zhang, J. Rao et al., "Construction and analysis of suppression subtractive hybridization library for Saccharum arundinaceum Retz. leaves exposed to drought stress," Acta Agronomica Sinica, vol. 33, pp. 961-967, 2007.

[17] Y. X. Que, W. Li, J. S. Xu, L. P. Xu, and M. Q. Zhang, "A simple and versatile protocol for isolation of RNA from plant, fungi and animal," Journal of Agriculture, Science and Technology, vol. 2, pp. 63-65, 2008.

[18] J. Bhati, H. Sonah, T. Jhang, N. K. Singh, and T. R. Sharma, "Comparative analysis and EST mining reveals high degree of conservation among five Brassicaceae species," Comparative and Functional Genomics, vol. 2010, Article ID 520238, 2010.

[19] N. O. Ozgenturk, F. Oruç, U. Sezerman et al., "Generation and analysis of expressed sequence tags from Olea europaea L.", Comparative and Functional Genomics, vol. 2010, Article ID 757512, 9 pages, 2010.

[20] Y. X. Que, L. P. Xu, J. S. Xu, J. S. Zhang, M. Q. Zhang, and R. K. Chen, "Selection of control genes in Real-time qPCR analysis of gene expression in sugarcane," Chinese Journal of Tropical Crops, vol. 30, pp. 274-278, 2009.
[21] K. J. Livak and T. D. Schmittgen, "Analysis of relative gene expression data using real-time quantitative PCR and the 2- ${ }^{\Delta \Delta}$ CT method," Methods, vol. 25, no. 4, pp. 402-408, 2001.

[22] Y. X. Que, J. X. Liu, L. P. Xu, J. L. Guo, J. S. Xu, and R. K. Chen, "Molecular cloning and expression analysis of a zeta-class glutathione S-transferase gene in sugarcane," African Journal of Biotechnology, vol. 10, no. 39, pp. 7567-7576, 2011.

[23] Y. X. Que, J. X. Liu, L. P. Xu, J. L. Guo, J. S. Xu, and R. K. Chen, "Molecular cloning and characterization of a cytoplasmic cyclophilin gene in sugarcane," African Journal of Biotechnology, vol. 10, no. 42, pp. 8213-8222, 2011.

[24] Y. X. Que, J. X. Liu, L. P. Xu, J. L. Guo, and R. K. Chen, "Molecular cloning and expression analysis of an Mnsuperoxide dismutase gene in sugarcane," African Journal of Biotechnology, vol. 11, no. 3, pp. 552-560, 2012.

[25] E. Bell and J. E. Mullet, "Lipoxygenase gene expression is modulated in plants by water deficit, wounding, and methyl jasmonate," Molecular and General Genetics, vol. 230, no. 3, pp. 456-462, 1991.

[26] G. L. Jia, H. P. Dai, B. L. Feng, S. Q. Zhang, and S. W. Zhang, "Biochemical characteristics in Broomcorn Millet (Panicum miliaceum L.) seedlings under PEG simulated drought stress," Acta Botanica Boreali-Occidentalia Sinica, vol. 28, pp. 20732079, 2008.

[27] Y. X. Que, J. W. Lin, X. X. Song, L. P. Xu, and R. K. Chen, "Differential gene expression in sugarcane in response to challenge by fungal pathogen Ustilago scitaminea revealed by cDNA-AFLP," Journal of Biomedicine and Biotechnology, vol. 2011, Article ID 160934, 10 pages, 2011.

[28] Y. X. Que, Z. X. Yang, L. P. Xu, and R. K. Chen, "Isolation and identification of differentially expressed genes in sugarcane infected by Ustilago scitaminea," Acta Agronomica Sinica, vol. 35, no. 3, pp. 452-458, 2009.

[29] J. M. Alonso, T. Hirayama, G. Roman, S. Nourizadeh, and J. R. Ecker, "EIN2, a bifunctional transducer of ethylene and stress responses in Arabidopsis," Science, vol. 284, no. 5423, pp. 2148-2152, 1999.

[30] S. Q. Cao, S. T. Jiang, and R. X. Zhang, "Evidence for a role of Ethylene-Insensitive 2 gene in the regulation of the oxidative stress response in Arabidopsis," Acta Physiologiae Plantarum, vol. 28, no. 5, pp. 417-425, 2006.

[31] Y. N. Wang, C. Liu, K. X. Li et al., "Arabidopsis EIN2 modulates stress response through abscisic acid response pathway," Plant Molecular Biology, vol. 64, no. 6, pp. 633-644, 2007.

[32] Z. H. Sun, C. Wen, Z. Y. Chen et al., "A role for EthyleneInsensitive 2 gene in the regulation of the ultraviolet- $B$ response in Arabidopsis," Acta Physiologiae Plantarum, vol. 33, no. 3, pp. 1025-1030, 2011.

[33] A. F. El Sheikh and M. G. Klotz, "Ammonia-dependent differential regulation of the gene cluster that encodes ammonia monooxygenase in Nitrosococcus oceani ATCC 19707," Environmental Microbiology, vol. 10, no. 11, pp. 3026-3035, 2008.

[34] S. Luan, "Signalling drought in guard cells," Plant, Cell and Environment, vol. 25, no. 2, pp. 229-237, 2002.

[35] L. Xiong, M. Ishitani, H. Lee, and J. K. Zhu, "The Arabidopsis LOS5/ABA3 locus encodes a molybdenum cofactor sulfurase and modulates cold stress- and osmotic stress-responsive gene expression," Plant Cell, vol. 13, no. 9, pp. 2063-2083, 2001.

[36] N. Nieves, M. E. Martínez, R. Castillo, M. A. Blanco, and J. L. González-Olmedo, "Effect of abscisic acid and jasmonic acid on partial desiccation of encapsulated somatic embryos 
of sugarcane," Plant Cell, Tissue and Organ Culture, vol. 65, no. 1, pp. 15-21, 2001.

[37] N. Beaudoin, C. Serizet, F. Gosti, and J. Giraudat, "Interactions between abscisic acid and ethylene signaling cascades," Plant Cell, vol. 12, no. 7, pp. 1103-1115, 2000.

[38] Q. Liu, G. Y. Zhang, and S. Y. Chen, "The structure and regulation of plant transcription factors," Chinese Science Bulletin, vol. 45, pp. 1465-1474, 2000.

[39] L. J. Zhang, J. J. Huan, Y. H. Ruan, and Y. X. Guan, "Application of polyethylene glycol in the study of plant osmotic stress physiology," Plant Physiology Communications, vol. 40, pp. 361-364, 2004. 

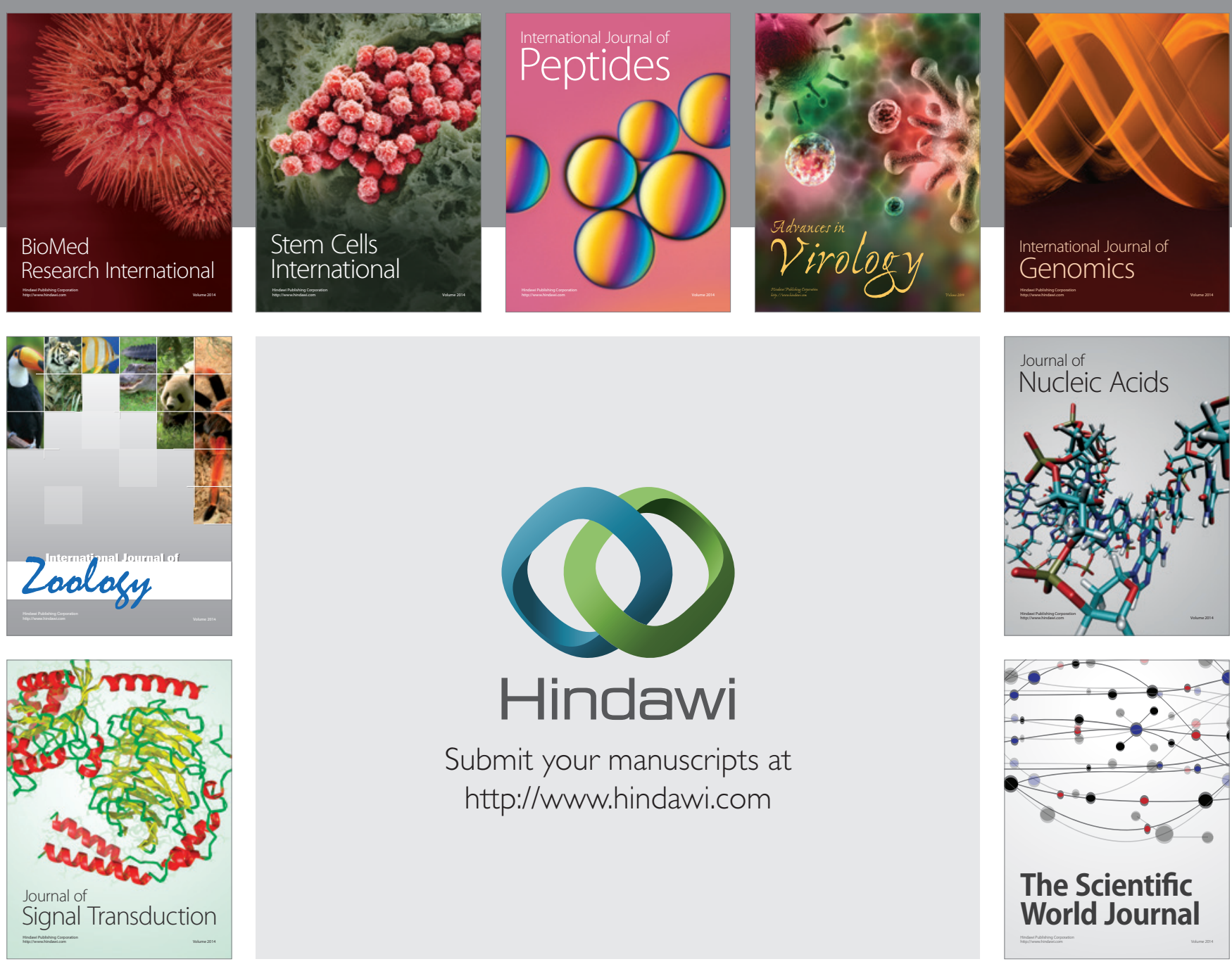

Submit your manuscripts at

http://www.hindawi.com
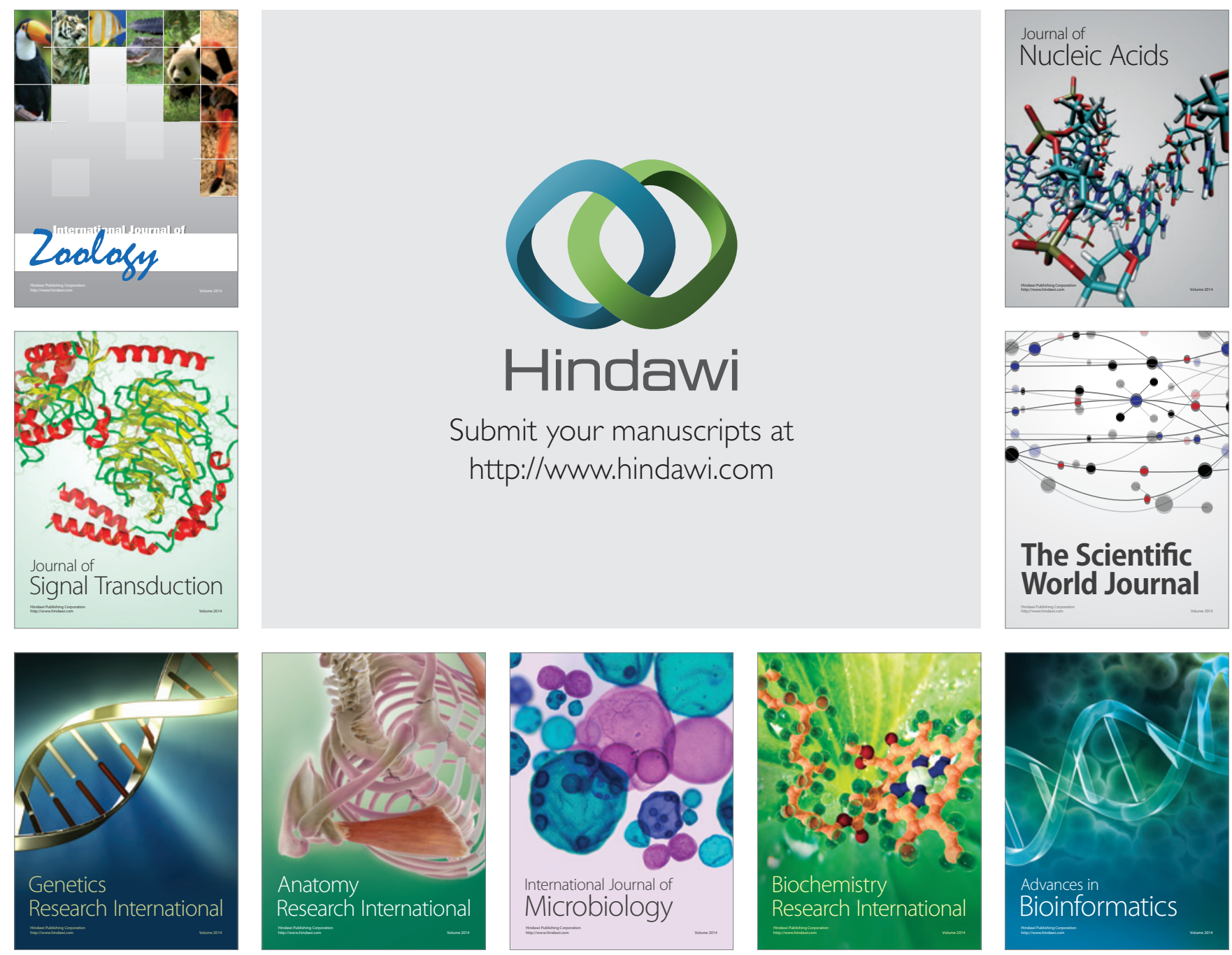

The Scientific World Journal
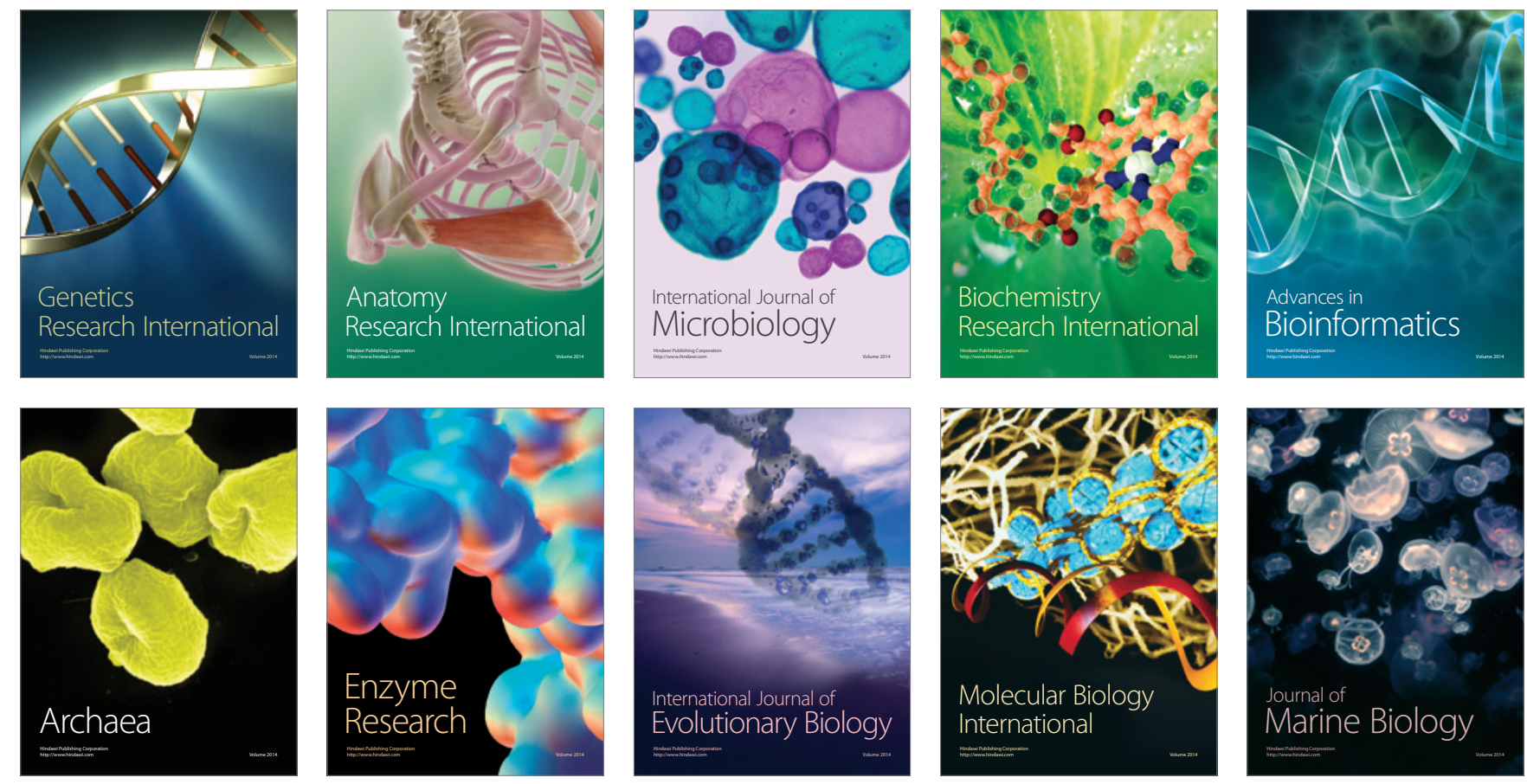